\title{
40. ELASTIC-WAVE VELOCITIES IN JURASSIC-AGE OCEANIC CRUST FROM ANALYSIS OF SONIC FULL WAVEFORM LOGS IN HOLE 801C ${ }^{1}$
}

\author{
Daniel Moos, ${ }^{2}$ Mark Van Schaack, ${ }^{2}$ and Hisao Ito ${ }^{3}$
}

\begin{abstract}
Using sonic full waveforms recorded by a borehole compensated logging sonde during Leg 144, we determined $P$-and $S$-wave velocities in the uppermost basement interval (from 480 to $~ 560 \mathrm{mbsf}$ ) of Jurassic crust penetrated by Hole $801 \mathrm{C}$. The basement consists of three principal units: an uppermost $~ 157$-Ma alkali basalt, erupted off-axis; a zone of hydrothermal deposits; and a section of $\sim 167$-Ma mid-ocean ridge tholeiites. In the alkali basalts, $V_{p}$ ranges from 4.8 to 5.1 and $V_{s}$ ranges from 2.4 to $2.6 \mathrm{~km} / \mathrm{s}$, yielding $V_{p} / V_{s}$ between 1.9 and 2.0 . In the tholeiites, $V_{p}$ ranges from 5.2 to 6.2 and $V_{s}$ ranges from 2.8 to $3.4 \mathrm{~km} / \mathrm{s}$, yielding $V_{p} / V_{s}$ between 1.75 and 1.85 . We were unable to confirm the extremely low $P$-wave velocities reported previously within sections of the hydrothermal interval. Within the basalts, low-velocity zones mark the boundaries between individual lithostratigraphic units. A comparison of sonic log velocities within crusts of a wide variety of ages with laboratory-determined ultrasonic velocities reveals that (1) lower average in situ velocities in young crust are a consequence of the presence of macroscopic voids and fractures and of systematic sampling bias; (2) these effects are minimized in old crust by the infilling of fractures and voids and by a decrease in sampling bias in older, more altered basalts; (3) velocities within pillows and interflow zones never reach values equivalent to those in massive units; and (4) alteration of the basalt matrix can significantly reduce its velocity. Velocities, therefore, are controlled by the relative percentages of pillows and flows, the progressive increase in velocity within the pillows resulting from infilling, and an alteration-dependent decrease in velocities within the basalt matrix with increasing crustal age.
\end{abstract}

\section{INTRODUCTION}

Ocean Drilling Program (ODP) Hole $801 \mathrm{C}$ penetrates the uppermost $134 \mathrm{~m}$ of $\sim 167$-Ma oceanic crust beneath $460 \mathrm{~m}$ of sediments in the Pigafetta Basin of the western Pacific Ocean (see site map preceding title page). As such, Hole $801 \mathrm{C}$ represents the deepest penetration yet of Jurassic-age oceanic basalts. Consequently, data gathered in this hole will form the basis for inferences regarding the evolution and characteristics of very old crust.

Hole $801 \mathrm{C}$ was first drilled during ODP Leg 129. Core recovery was quite high (60\%) as compared with recovery in holes drilled into younger crust reaching similar depths (Shipboard Scientific Party, 1990). Hole $801 \mathrm{C}$ penetrated three distinct lithologic intervals (Fig. 1). The uppermost interval is composed of alkali basalts of ocean-island affinity (Floyd and Castillo, 1992). Below the alkali basalts is a hydrothermal deposit composed primarily of a quartz-cemented yellow goethite. Below the hydrothermal zone lie tholeiitic basalts. The age of the tholeiites is about $167 \mathrm{Ma}$, whereas the alkali basalts are about $10 \mathrm{~m}$.y. younger and are interpreted to be erupted in an off-axis environment (Pringle, 1992). The alkali basalts are quite highly altered (Alt et al., 1992) in comparison with the tholeiites, and they are characterized by additional vein-filling calcite and a slightly higher $\delta^{18} \mathrm{O}$. A 5 -m-thick interval within the tholeiites immediately below the hydrothermal deposit is also highly altered, probably by hydrothermal fluid circulation during deposition, as is a 5-m interval within the alkali basalts immediately overlying the hydrothermal deposit.

An excellent set of geophysical logs was recorded in Hole 801C from the bottom of casing at $\sim 480$ meters below seafloor (mbsf) to near total depth during Leg 144 (Fig. 1). The logs reveal details of the depth distribution and characteristics of the basement rock types that allow refinements of the results obtained through analysis of the recovered core. This is discussed in more detail by Jarrard et al. (this

\footnotetext{
Haggerty, J.A., Premoli Silva, I., Rack, F., and McNutt, M.K. (Eds.), 1995. Proc. $O D P$, Sci. Results, 144: College Station, TX (Ocean Drilling Program).

Department of Geophysics, Stanford University, Stanford, CA $94305-2215$, U.S.A.

${ }^{3}$ Geological Survey of Japan, 1-1-3 Higashi, Tsukuba-shi, Ibaraki 305, Japan.
}

volume). Larson et al. (1993) discussed the results of flowmeter experiments that revealed extremely high permeabilities, which they suggested, based on analysis of the logs, were largely confined to the depth interval including the hydrothermal deposit.

As can be seen from Figure 1, the hydrothermal deposit and the adjacent units are associated with unusually low compressional velocity, as well as with low measured density and resistivity and high measured porosity. Variations in gamma activity are a result of both intrinsic differences in the amount of radioactive elements within the original materials and the effects of alteration (Jarrard et al., this volume). A caliper log reveals that the hole is substantially enlarged and extremely irregular throughout this interval. Because sonic logs through such intervals are often unreliable, it is important to verify the very low $P$-wave velocities recorded within portions of this section.

During the logging campaign at Hole $801 \mathrm{C}$, full waveform data were recorded using the Schlumberger BHC logging sonde. These data provide an opportunity to verify the results from the sonic log. More importantly, they provide an opportunity to determine shearwave velocity. Determinations of both $P$ - and $S$-wave velocity allow calculation of the $V_{p} / V_{s}$ ratio, which is sensitive to the distribution and properties of cracks and pores that record the detailed history of alteration and aging of the oceanic crust.

Our results verify the accuracy of the original sonic logs throughout most of the well. In addition, we observe systematic variations in $V_{p} / V_{s}$ both between and within the alkali and tholeiitic basalts that are associated with their deposition and alteration. Unfortunately, we have not been able to verify the validity of the extremely low $(\sim 2$ $\mathrm{km} / \mathrm{s}$ ) $P$-wave velocities seen in the original velocity log within the hydrothermal zone.

\section{DATA AND METHODOLOGY}

The borehole compensated $(\mathrm{BHC})$ sonic logging tool contains two sources and four receivers, which are configured such that two of the receivers are used with each source, as shown in Figure 2 (Schlumberger, 1987). During logging, the arrival times of $P$-waves refracted along the borehole wall are determined using a thresholdpicking technique on the analog waveforms. The sources are triggered and the data are recorded in such a way that each depth interval 


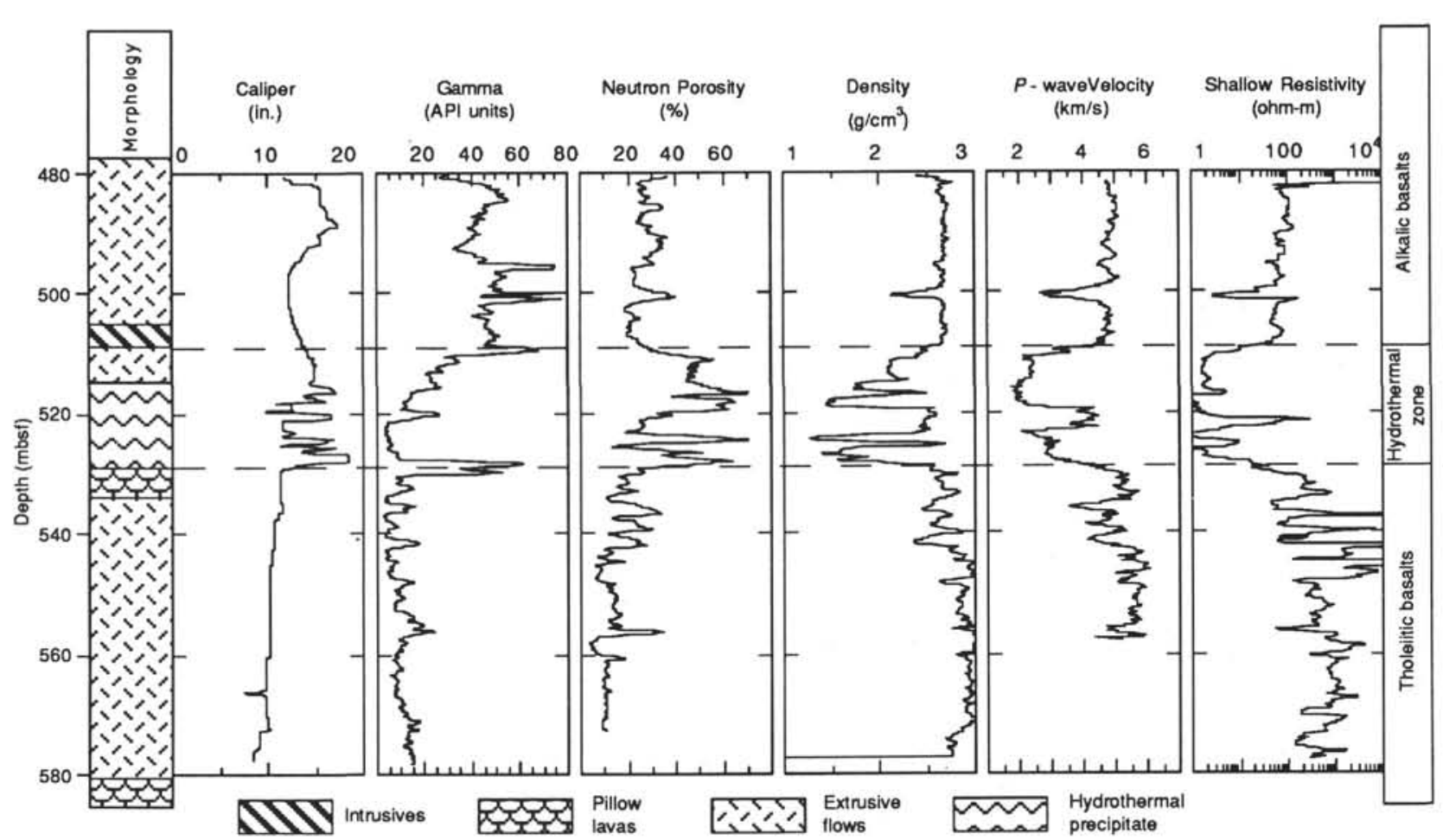

Figure 1. Well logs and lithostratigraphy of Hole 801C (after Shipboard Scientific Party, 1993).

within which the arrival times are measured is covered several times to minimize the impact of errors in picking as well as of borehole size changes and tool tilt. As was the case in Hole 801C, the full waveforms of arrivals at each receiver can be digitized and stored for further analysis. Five hundred samples are recorded at $10-\mu$ s intervals for each waveform.

Figure 3 shows one of the sets of waveforms recorded at a $3 \mathrm{ft}$ source-receiver spacing. Overlain on the waveform data are the arrival-time picks obtained during logging (small dots). Overall, the arrival-times appear to be accurate. Small differences between the arrival-time and the leading edge of the $P$-wave may reflect the fact that the picks were not necessarily made on the actual displayed waveform, but rather on a waveform that is recorded within a 6-in. $(0.15-\mathrm{m})$ interval around it. However, errors are apparent in a number of sections. These include the base of a zone of late arrivals at about $536 \mathrm{mbsf}$ and isolated thin zones of early arrivals within and surrounding the hydrothermal zone. Furthermore, it is not clear whether the picks within the interval 515-520 mbsf (the upper section of the hydrothermal zone) represent the $P$-wave arrival. These characteristics are similar for all four of the source-receiver pairs.

The first step in our analysis was to correct the Schlumberger picks based on direct comparison with the recorded waveforms. We used an algorithm that allows manual picks to be "snapped" to the nearest peak to avoid the influence of a DC offset on the picked arrival times. The corrected picks are also shown in Figure 3. The first thing to note is that the Schlumberger picks are slightly earlier than ours. This is because the Schlumberger picks are at a zero crossing and ours are at the next peak. More importantly, we have been able to follow more accurately the first arrivals through the hydrothermal zone and within other isolated zones of late arrivals. We also have extended our picks for this measurement to include all of the waveforms from total depth to the point where the arrivals are attenuated as the tool enters the pipe.

We then conducted a similar analysis of the shear-wave arrivals. As a guide in identifying the $S$-wave arrivals, we calculated a traveltime estimate based on the $P$-wave arrival time and an assumed $V_{p} / V_{s}$ of $\sqrt{3}$. These estimates lay slightly ahead of the high-amplitude shear/
pseudo-Rayleigh wave arrival. We then corrected the picks interactively to produce the results shown along with the two $P$-wave arrival-time determinations in Figure 3. The shear wave is quite strong within the tholeiitic and alkali basalts, including zones of late arrivals such as the intervals at 536 and 499 mbsf. It was not possible to make $S$-wave picks within the hydrothermal zone, except for the central high-velocity section. These were defaulted, therefore, to the constant arrival-time value of about $700 \mu \mathrm{s}$.

We also calculated the shear-wave velocity using the modified (interactive) semblance technique described previously by Moos (1988) and Moos et al. (1990). Semblance is a technique that typically is employed to take advantage of the multiplicity of data available when a single shot is recorded by multiple receivers (Kimball and Marzetta, 1984). Such a technique has been used previously on twochannel data (Barton et al., 1989). Comparison of the velocities determined by semblance to those determined from the picks may reveal the degree to which contamination of the shear-wave arrival either by "leaky" P energy or by the pseudo-Rayleigh wave affects the results (Paillet and Cheng, 1991).

We computed new formation $P$ - and $S$-wave velocity logs by dividing the $2 \mathrm{ft}(\sim 0.6 \mathrm{~m})$ interval between the receiver pairs by the difference between the appropriately depth-shifted, interactively picked traveltimes. R. Jarrard (unpubl. data, 1993) also provided us with copies of a filtered $P$-wave log based on Schlumberger's picks. With the addition of the semblance-determined shear-wave log, we had a total of four independent velocity determinations (two shear and two compressional) within Hole 801C.

\section{RESULTS AND DISCUSSION}

The first step in the analysis of our results was to compare the velocities determined using the different methods. Figure 4 shows cross-plots of our manually picked $P$ - and $S$-wave velocities with the Schlumberger P-picks and the semblance shear velocities, along with histograms of the differences expressed as a percentage of the average velocity. There are only a few isolated cases in which the difference in 
$P$-wave velocity is more than $10 \%$, and these are evenly distributed between cases in which the Schlumberger velocities are higher or lower than our determinations. The shear-wave velocities calculated from the manual picks and by semblance are also similar. However, in this case a substantial bias is present in the data, in that the intervals with large differences are characterized by much higher semblancedetermined velocities. These correspond (as will be apparent later) to isolated intervals of low velocity (the intervals of late arrivals in Fig. 3 ) and to the hydrothermal zone. The reason is twofold: first, there is a tendency during semblance analysis of "cycle skipping" to produce a smoother velocity log, a tendency that is aggravated by spatial aliasing when analyzing waveforms recorded with a $2 \mathrm{ft}(0.6 \mathrm{~m})$ receiver spacing; second, the semblance window may also include energy from the pseudo-Rayleigh wave mode, for which the velocity is less variable than for the $S$-wave.

We present the velocity logs and computed $V_{p} / V_{s}$ in Figure 5. Figure $5 \mathrm{~A}$ shows Schlumberger $V_{p}$ and semblance $V_{s}$, and Figure 5B shows the $V_{p}$ and $V_{s}$ calculated from the manual picks. In Figure 5C, we present a subset of the data for which the pairs of logs are within $0.2 \mathrm{~km} / \mathrm{s}\left(<8 \%\right.$ difference for $V_{s}$ and $<4 \%$ difference for $\left.V_{p}\right)$. Filtering the data in this manner discriminates against bad picks and cycle skips, and it provides logs with a high degree of reliability. However, it will also eliminate sections within which one of the two methods may have given the correct result.

The gross-scale features of the $P$-wave logs are quite similar, validating the original log over most of the hole. However, one prominent feature of the new $P$-wave $\log$ is the presence of a few narrow, high-velocity intervals corresponding to the missed Schlumberger picks described above (e.g., at 518 and 526 mbsf). These zones can also be seen in the porosity and density logs (Fig. 1). In the interval from 510 to $515 \mathrm{mbsf}$, both logs indicate a relatively constant velocity of about $2.5 \mathrm{~km} / \mathrm{s}$. This is not surprising, as they were both determined based on picking the same arrival time (see Fig. 3). We do not present the results from 515 to $520 \mathrm{mbsf}$ because we had difficulty in identifying the $P$-and $S$-wave arrivals in this interval.

The shear-wave logs are also similar, except that the semblance $V_{s}$ does not always show the presence of narrow, low-velocity zones (e.g., at $500 \mathrm{mbsf}$ ). As mentioned above, this may be a result of either contamination of the semblance-determined velocity log by the pseudoRayleigh wave or of spatial aliasing and the tendency during analysis to pick the "smoothest" path through slowness-depth space. As the picks are made at the beginning of the shear/pseudo-Rayleigh packet, they are less likely to be affected.

The velocity data (Fig. 5C) and the $V_{p} / V_{s}$ data (Fig. 5D) allow us to summarize the characteristics of the uppermost $80 \mathrm{~m}$ of the crust at Site 801 . In the alkali basalts, average $P$-wave velocities of $4.8-5.1$ $\mathrm{km} / \mathrm{s}$ appear to be independent of depth, with the exception of a small stepwise decrease in the interval from 502 to 510 mbsf. Shear-wave velocities range from 2.4 to $2.6 \mathrm{~km} / \mathrm{s} . V_{p} / V_{s}$ is about $1.9-2.0$ above 500 $\mathrm{m}$ and slightly lower (1.85 to 1.9 ) in the interval from 502 to $510 \mathrm{mbsf}$. Slightly lower neutron porosities in this interval, combined with a lack of change of density, suggest that this zone is characterized by a slightly more altered groundmass accompanied by a small reduction in crack porosity.

Velocities are more variable in the tholeiites. The 5-m interval immediately below the hydrothermal section has $P$-wave velocities of $5.3-5.4 \mathrm{~km} / \mathrm{s}$ and $S$-wave velocities of about $3 \mathrm{~km} / \mathrm{s}$, yielding $V_{p} / V_{s} \approx$ 1.8. This pillow lava sequence is characterized by higher gamma activity (Fig. 1) and by intense blue-green alteration resulting from diffuse circulation of hydrothermal fluids associated with the emplacement of the hydrothermal deposit (Alt et al., 1992). Examination of the magnetometer log recorded during Leg 144 also reveals the possible effects of alteration on the magnetic field (Ito et al., this volume). Below the altered zone, $P$-wave velocities range from about 4 to $6 \mathrm{~km} / \mathrm{s}$. A 6-m-thick zone from 542 to $548 \mathrm{mbsf}$ has $P$-wave velocities above 6 $\mathrm{km} / \mathrm{s}$ and $S$-wave velocities of $3.4 \mathrm{~km} / \mathrm{s}$, again yielding a $V_{p} / V_{s}$ of about 1.8. This zone is underlain by a thin low-velocity interval. Velocities in

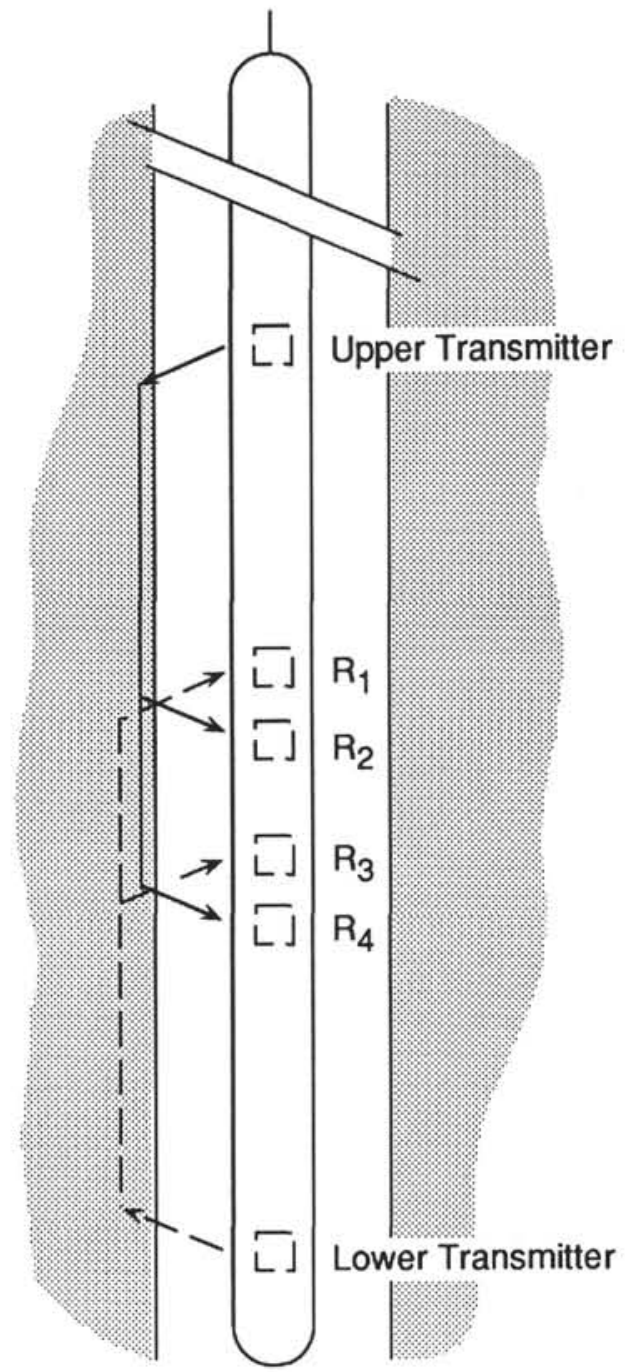

Figure 2. The Schlumberger BHC logging sonde employs two independent groups of sources and receivers to record the traveltimes of waves refracted up and down the well bore at distances of about 0.9 and $1.5 \mathrm{~m}$ from the sources. The traveltime differences provide a measure of the $P$-wave velocity of the formation between the receivers. Because of the geometry of the sonde, corrections can be made for tool tilt and changes in hole size.

the interval from 550 to 555 mbsf are relatively constant $\left(V_{p} \approx 5.5-5.7\right.$ $\mathrm{km} / \mathrm{s}$ and $V_{s} \approx 3.1 \mathrm{~km} / \mathrm{s}$, yielding $V_{p} / V_{s} \approx 1.75-1.8$ ). Another lowvelocity zone separates this from the next unit, which, although it was only sampled at its top, appears to have slightly higher velocities $\left(V_{p}>\right.$ $6 \mathrm{~km} / \mathrm{s}$ and $V_{s}>3.5 \mathrm{~km} / \mathrm{s}$ ). The high velocities at the bottom of the logged interval probably extend to at least $575 \mathrm{mbsf}$, based on core measurements and on the resistivity, neutron porosity, and density logs, all of which reached greater depth (Fig. 1).

No $P$-wave velocities as low as those reported from the original sonic log were measured in core from the hydrothermal interval or from the overlying highly altered alkali basalts, which suggests either (1) sampling is biased, (2) the log measurements are affected by largescale structure, or (3) the log measured velocities were too low. We were not able to verify the extremely low velocities found in the original log over the interval from 510 to 520 mbsf. We suspect that the original $\log$ recorded the shear wave from 510 to $515 \mathrm{mbsf}$; we were unable to determine reliably the identity of the picked event from 515 to $520 \mathrm{mbsf}$. Aside from these intervals, it is likely that our final log (Fig. 5C) is accurate because most of the picks made during logging are similar to those made manually (Fig. 3). 


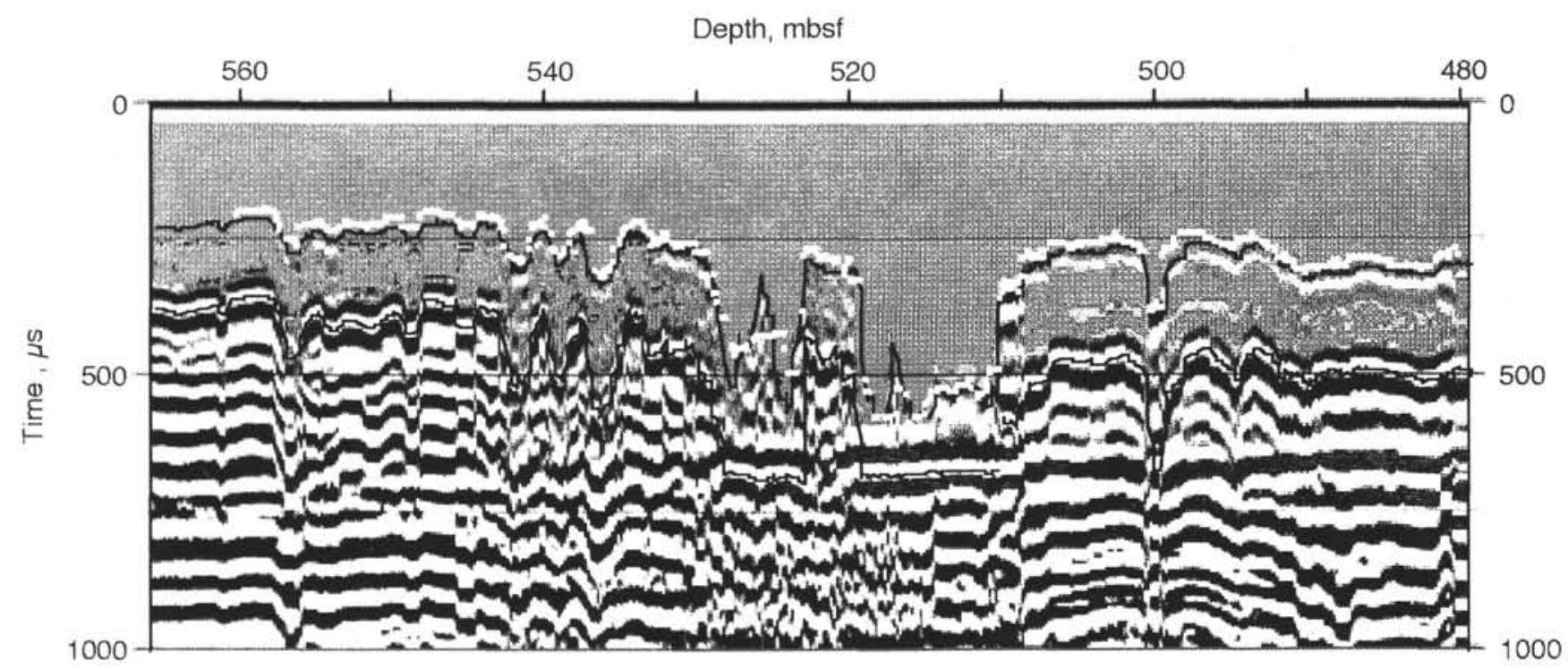

Figure 3. Waveforms recorded with a $3 \mathrm{ft}$ source-receiver offset within Hole $801 \mathrm{C}$, shown with the Schlumberger picks made during logging (white dots) and manual picks of the $P$ - and $S$-wave arrivals (black lines).

A

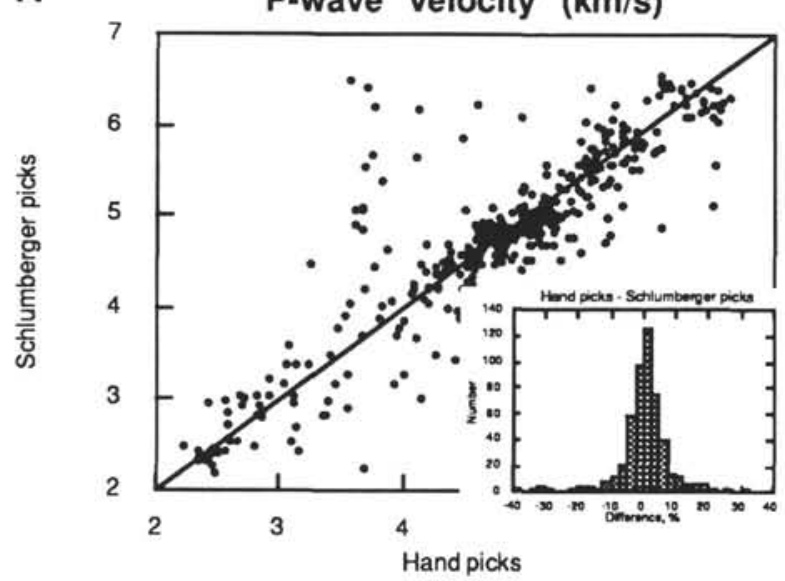

B

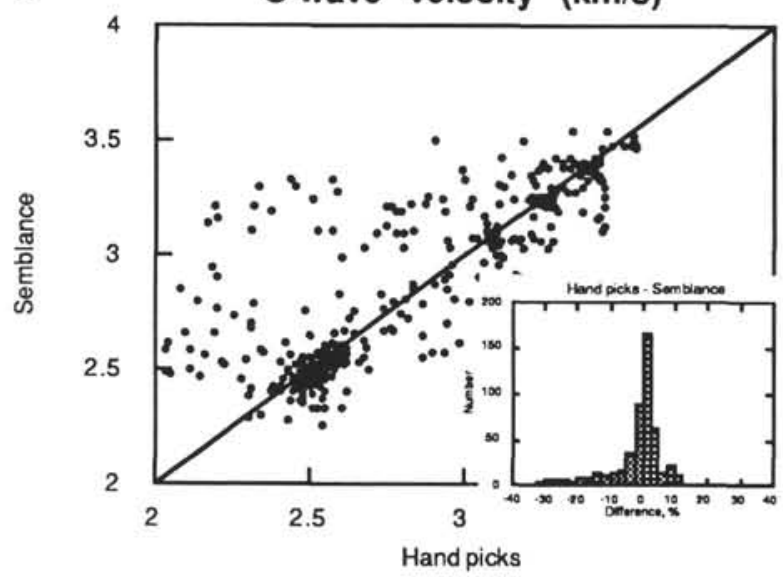

Figure 4. A. Crossplots of $P$-wave velocities determined using Schlumberger and manual picks. B. Crossplots of $S$-wave velocities determined using manual picking and the semblance technique. Also shown in each case is a histogram of the percentage difference between the individual values at each depth.
It is relatively straightforward to reconcile most of the velocities measured in the laboratory with our new results, given the depth uncertainties associated with incomplete recovery. For example, the basalt from a depth of 524 mbsf measured by Wallick et al. (1992) may have come from the narrow high-velocity interval in the logs at about $526 \mathrm{mbsf}$, a result not inconsistent with the core recovery. Such narrow high-velocity intervals can be seen in the full waveforms as isolated sections of early $P$-wave arrivals; they can also be seen in the other logs (Fig. 1). The samples from the altered alkali basalts (510$515 \mathrm{mbsf}$ ), within which our results suggest a much lower in situ than laboratory velocity, may have come from the narrow high-velocity interval at $518 \mathrm{mbsf}$, although this is a bit harder to reconcile than the other discrepancies.

The shipboard measurements agree quite well with the logs in the alkali basalts, given the depth uncertainties associated with incomplete recovery. Thus, it appears that the properties of these materials may be an unbiased representation of those in situ. Within the tholeiites, velocities measured on the cores span the range of the logged velocities. Furthermore, the sample depths of the low-velocity materials can be adjusted to match the locations of low-velocity zones in the log without violating the depth constraints imposed by coring. This suggests that core recovered in the tholeiites is also more representative of the range of in situ materials than is typical of recovery from younger crust. In addition, the properties of the low-velocity zones are controlled by their microstructure and material properties, rather than by macroscopic voids and/or fractures, which are usually invoked to explain discrepancies between log and core properties in younger crust, implying that these have been largely sealed. This is supported by the low permeability of the well-bore interval below 542 mbsf (Larson et al., 1993), in spite of the fact that it contains several low-velocity zones. The persistence of low velocities in these zones could be a consequence either of the accessibility of these materials to circulating fluids, which may have caused them to be more altered than the flow interiors, or of the fact that they were originally more porous, and infilling did not entirely eliminate the differences in their physical properties compared to the adjacent materials. The similarity of the core and log properties of the more massive materials between the low-velocity zones is typical of massive flows in crust of all ages.

It is generally assumed that gamma activity is a good predictor of the degree of alteration, because unaltered tholeiitic basalts have 


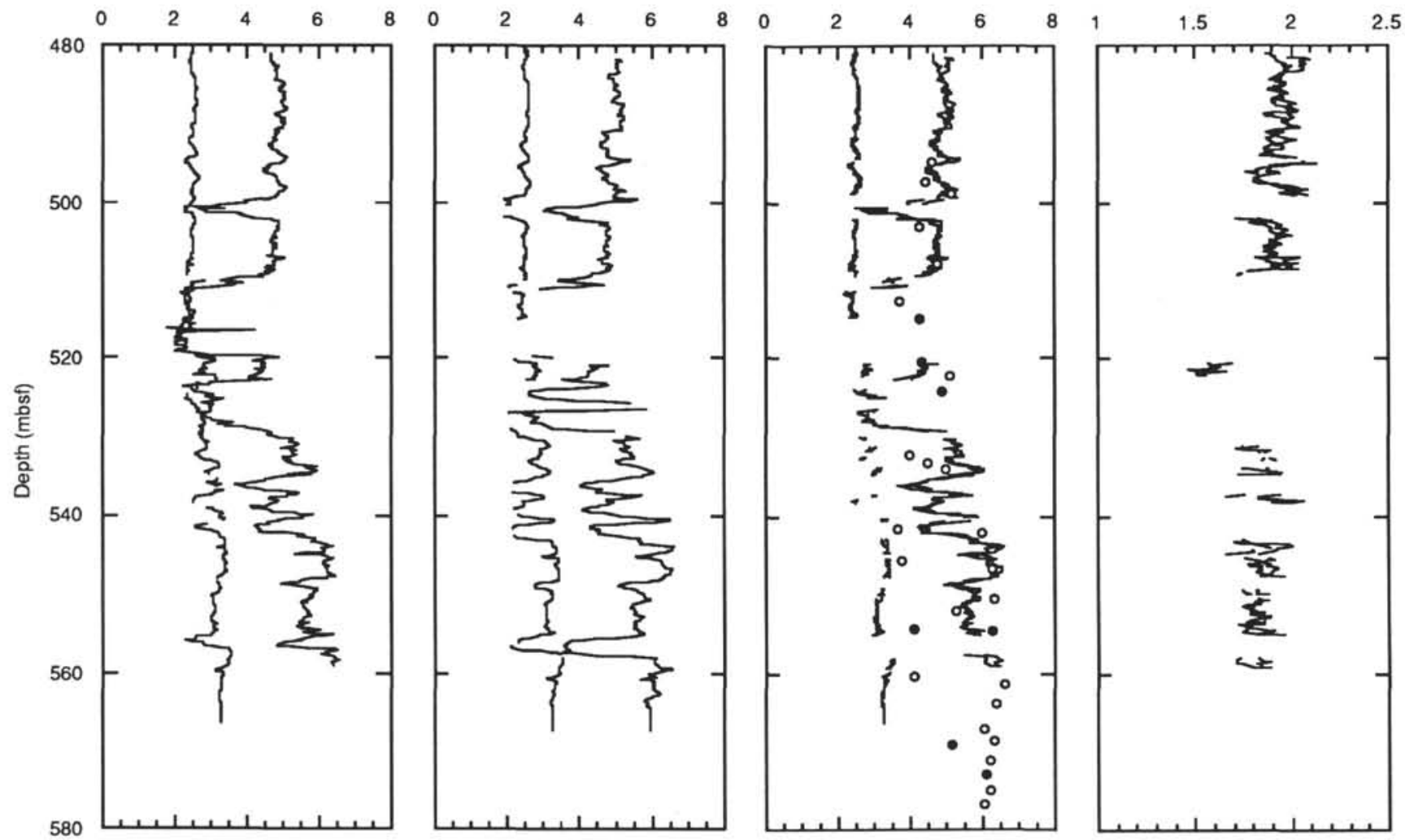

Figure 5. Elastic-wave velocities as a function of depth in Hole 801C. A. Compressional velocity determined from the Schlumberger picks and shear-wave velocity determined by semblance. B. Compressional and shear velocities determined from the manual picks. C. Combined results where the velocities differed in each case by less than $0.2 \mathrm{~km} / \mathrm{s}$. Also shown are the compressional wave velocities measured in saturated minicores on board during Leg 129 (open circles; Shipboard Scientific Party, 1990) and on shore. Values are corrected by linearly extrapolating the velocity data to that appropriate for the in situ effective pressure (closed circles; Wallick et al., 1992). D. $V_{p} / V_{s}$ calculated from the logs shown in Figure 5C.

relatively small amounts of radioactive elements, and alteration products are often more potassium rich. Jarrard et al. (this volume) discuss this in more detail and conclude that the ratio $\mathrm{Th} / \mathrm{K}_{2} \mathrm{O}$ is a better indicator of alteration in the tholeiites. We find that the low-velocity zones in both the tholeiites and the alkali basalts are also zones of high total gamma activity relative to adjacent zones (Fig. 1), suggesting that the low-velocity intervals are associated with enrichment in radioactive elements.

The characteristic alternation within the basalts of intervals of high velocity separated by narrow low-velocity zones is a consequence of their depositional history both on- and off-axis. This arises because depositional flow units generally are separated by zones of less coherent or more porous materials, either because of the overflow of flowfront breccias or the exposure of flow surfaces to deposition and interaction with seawater and the possible effects of benthic fauna. Such an interpretation was applied previously to data from Sites 504 (5.4 Ma), 395 (7.3 Ma), and 418 (110 Ma) (Moos et al., 1990; Pezard, 1990). Our results strongly suggest that these differences are present in both young and old crust, allowing lithostratigraphy based on cores to be refined using geophysical logs regardless of crustal age (see also Jarrard et al., this volume).

Figure 6 shows the upper few hundred meters of velocity logs in Holes 395A, 418A, and 504B, along with laboratory-measured velocities (figure modified from Moos et al., 1990). The most obvious feature of these data is that there is not a simple trend of increased log velocity with increased age. As pointed out by Moos et al. (1990), the velocity profiles are dominantly controlled by the relative percentages of pillows and flows. Although the flow properties change rela- tively little, pillows generally have higher average velocities in older crust than in young crust. However, velocities are lower in pillows than in flows even in very old crust, which accounts for the persistent control of velocity by the relative percentages of each.

Laboratory-determined velocities increasingly represent the range of $\log$ velocities with increasing age. For example, in Holes 395A and 504B (both < 6 Ma), most of the laboratory-determined velocities are higher than the log velocities within pillow intervals. In contrast, laboratory results from Holes $418 \mathrm{~A}$ and $801 \mathrm{C}$ (both $>100 \mathrm{Ma}$ ) appear to be more representative of the in situ results. Thus, the large-scale fractures and voids that strongly influence velocities within young crust are considerably less important in very old crust, as also suggested previously (e.g., Salisbury et al., 1988). Furthermore, the persistence of low-velocity zones in old crust is caused either by changes in the properties of the basalt matrix (e.g., a very high degree of alteration as a consequence of the accessibility of these intervals to circulating fluids) or by the intrinsically lower velocities of the infilling materials.

These results are consistent with other attempts to understand agerelated changes in seismic and core-measured velocities (Jacobson, 1992; Johnson and Semyan, 1994; Wilkens et al., 1991). These studies also attributed variations in properties to a combination of alteration of the basalt matrix, which leads to a reduction in velocities measured in samples and in massive flows in situ, and infilling of macroscopic voids and fractures, which increases the in situ seismic velocities. Our results also emphasize the importance of taking into account the relative percentages of pillows and flows in any attempt to understand the shallow velocity structure of oceanic crust, as pointed out by Moos et al. (1990) and more recently by Jarrard (in press). 

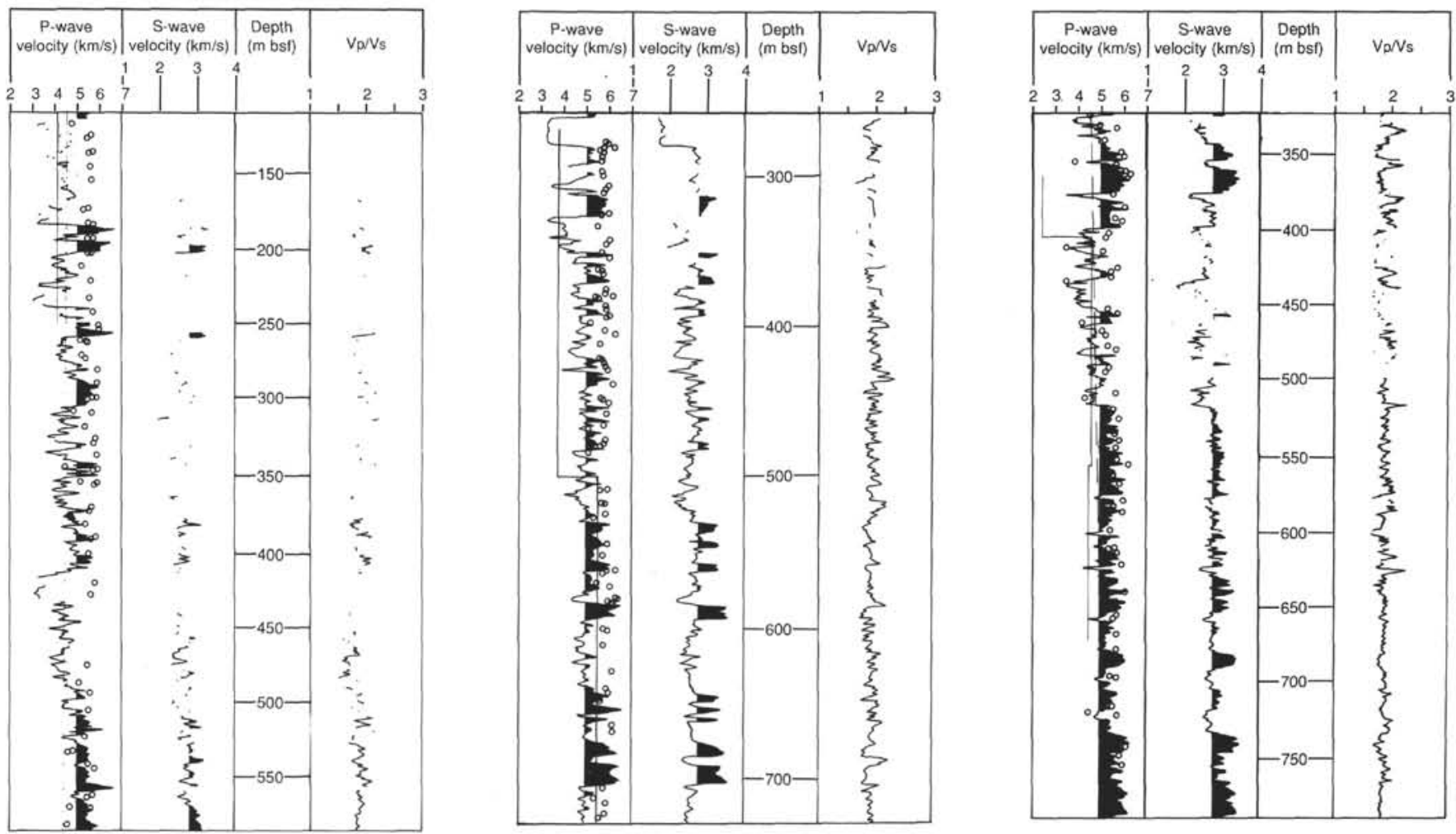

Figure 6. Compressional and shear velocities computed using multichannel sonic full waveform data by semblance analysis, and velocities determined in the laboratory in minicores (open circles) for Holes 395A (7.3 Ma), 504B (5.4 Ma), and 418A (110 Ma). Figure modified after Moos et al. (1990). Also shown are seismic interval velocities determined either from VSP data in Hole 504B (Shipboard Scientific Party, 1988), oblique seismic data in Hole 418A (Swift et al., 1988), or seismic refraction data at from Hole 395A (Jacobson et al., 1984; Purdy, 1987).

\section{CONCLUSIONS}

Our analysis demonstrates that full waveform data collected with the BHC logging sonde can be analyzed to improve the results of sonic logs by verifying measurements of $V_{p}$ and by allowing determination of $V_{s}$. The results reveal differences between and within the three major units penetrated by Hole $801 \mathrm{C}$. In the alkali basalts, $V_{p}$ varies from 4.8 to $5.1 \mathrm{~km} / \mathrm{s}, V_{s}$ is about $2.4-2.6 \mathrm{~km} / \mathrm{s}$, and $V_{p} / V_{s}$ is 1.9-2.0. In contrast, the tholeiites have systematically higher $V_{p}$ $(5.2-6.2 \mathrm{~km} / \mathrm{s})$ and $V_{s}(2.8-3.4 \mathrm{~km} / \mathrm{s})$, and a relatively constant $V_{p} / V_{s}$ (1.75-1.85). In both intervals, narrow low-velocity zones reveal details of the deposition and alteration history. Velocities within the hydrothermal zone and adjacent materials are less well constrained, and several narrow zones of high velocity within the section reveal details of its internal structure.

Comparison of sonic and core-measured velocities, in the Jurassic crust penetrated by Hole $801 \mathrm{C}$ as well as in crust of a variety of ages from other holes, confirms that two primary effects control the observed variation of velocity with age. First, macroscopic voids and fractures are infilled with alteration materials ranging from calcite to clays. Second, alteration of the basalt matrix can greatly reduce the velocities of the intact rock. Consequently, recovery improves markedly with age, such that the properties of the cores in some cases span the range of in situ properties. However, in spite of the effects of infilling, which can greatly reduce in situ permeabilities, low-velocity zones within pillows and between individual flow units persist to substantial ages.

\section{ACKNOWLEDGMENTS}

We would like to thank B.P. Wallick, D. Goldberg, and M. Salisbury for their thoughtful comments, all of which substantially improved the final version of this paper. The first author would also like to acknowledge support from the Geological Survey of Japan and Information and Mathematical Science Laboratory, Inc., during his visit to Tsukuba for the preliminary data analysis.

\section{REFERENCES}

Alt, J.C., France-Lanord, C., Floyd, P.A., Castillo, P., and Galy, A., 1992. Low-temperature hydrothermal alteration of Jurassic ocean crust, Site 801. In Larson, R.L., Lancelot, Y., et al., Proc. ODP, Sci. Results, 129: College Station, TX (Ocean Drilling Program), 415-427.

Barton, C., Moos, D., and Blangy, J.-P., 1989. Analysis of full waveform acoustic logging data at ODP Site 642 - outer Vøring Plateau. In Eldholm, O., Thiede, J., Taylor, E., et al., Proc. ODP, Sci. Results, 104: College Station, TX (Ocean Drilling Program), 953-964.

Floyd, P.A., and Castillo, P.R., 1992. Geochemistry and petrogenesis of Jurassic ocean crust basalts, Site 801. In Larson, R.L., Lancelot, Y., et al., Proc. ODP, Sci. Results, 129: College Station, TX (Ocean Drilling Program), 361-388.

\footnotetext{
Abbreviations for names of organizations and publications in ODP reference lists follow the style given in Chemical Abstracts Service Source Index (published by American Chemical Society).
} 
Jacobson, R.S., 1992. Impact of crustal evolution on changes of the seismic properties of the uppermost ocean crust. Rev. Geophys., 30:23-42.

Jacobson, R.S., Adair, R., and Orcutt, J., 1984. Preliminary seismic refraction results using a borehole seismometer in Deep Sea Drilling Project Hole 395A. In Hyndman, R.D., Salisbury, M.H., et al., Init. Repts. DSDP, 78 (Pt. 2): Washington (U.S. Govt. Printing Office), 783-792.

Jarrard, R. D., in press. Geological causes of geophysical aging of oceanic crust. Earth Planet. Sci. Lett.

Johnson, P., and Semyan, S., 1994. Age variation of the physical properties of oceanic basalts: implications for crustal formation and evolution. J. Geophys. Res., 99:3123-3134.

Kimball, C.V., and Marzetta, T.L., 1984. Semblance processing of borehole acoustic array data. Geophysics, 49:274-281.

Larson, R.L., Fisher, A.T., Jarrard, R.D., Becker, K., and Ocean Drilling Program Leg 144 Shipboard Scientific Party, 1993. Highly permeable and layered Jurassic oceanic crust in the western Pacific. Earth Planet. Sci. Lett., 119:71-83.

Moos, D., 1988. Elastic properties of 110-Ma oceanic crust from sonic full waveforms in DSDP Hole 418A. In Salisbury, M.H., Scott, J.H., et al., Proc. ODP, Sci. Results, 102: College Station, TX (Ocean Drilling Program), 49-62.

Moos, D., Pezard, P., and Lovell, M., 1990. Elastic wave velocities within ocean layer 2 from sonic full waveform logs in Deep Sea Drilling Project Holes 395A, 415A, and 504B. J. Geophys. Res., 95:9189-9207.

Paillet, F.L., and Cheng, C.H., 1991. Acoustic Waves in Boreholes: Boca Raton, FL (CRC Press).

Pezard, P.A., 1990. Electrical properties of mid-ocean ridge basalt and implications for the structure of the upper oceanic crust in Hole 504B. $J$. Geophys. Res., 95:9237-9264.

Pringle, M.S., 1992. Radiometric ages of basaltic basement recovered at Sites 800, 801, and 802, Leg 129, western Pacific Ocean. In Larson, R.L., Lancelot, Y., et al., Proc. ODP, Sci. Results, 129: College Station, TX (Ocean Drilling Program), 389-404.

Purdy, G.M., 1987. New observations of the shallow seismic structure of young oceanic crust. J. Geophys. Res., 92:9351-9362.
Salisbury, M.H., Scott, J.H., Auroux, C., Becker, K., Bosum, W., Broglia, C., Carlson, R., Christensen, N.I., Fisher, A., Gieskes, J., Holmes, M.A., Hoskins, H., Moos, D., Stephen, R., and Wilkens, R., 1988. Old oceanic crust: synthesis of logging, laboratory, and seismic data from Leg 102. In Salisbury, M.H., Scott, J.H., et al., Proc. ODP, Sci. Results, 102: College Station, TX (Ocean Drilling Program), 155-180.

Schlumberger, 1987. Log Interpretation Principles/Applications: Houston, TX (Schlumberger Educational Services).

Shipboard Scientific Party, 1988. Site 504: Costa Rica Rift. In Becker, K., Sakai, H., et al., Proc. ODP, Init. Repts., 111: College Station, TX (Ocean Drilling Program), 35-251. 1990. Site 801. In Lancelot, Y., Larson, R.L., et al., Proc. ODP, Init. Repts., 129: College Station, TX (Ocean Drilling Program), 91-170.

, 1993. Site 801. In Premoli Silva, I., Haggerty, J., Rack, F., et al., Proc. ODP, Init. Repts., 144: College Station, TX (Ocean Drilling Program), 313-329.

Swift, S.A., Stephen, R.A., and Hoskins, H., 1988. Structure of upper oceanic crust from an oblique seismic experiment at Hole 418A, Western North Atlantic. In Salisbury, M.H., Scott, J.H., et al., Proc. ODP, Sci. Results, 102: College Station, TX (Ocean Drilling Program), 97-124.

Wallick, B.P., Christensen, N.I., and Ballotti, D.M., 1992. High-pressure velocity measurements of Jurassic basalt, Leg 129. In Larson, R.L., Lancelot, Y., et al., Proc. ODP, Sci. Results, 129: College Station, TX (Ocean Drilling Program), 501-506.

Wilkens, R.H., Fryer, G.J., and Karsten, J., 1991. Evolution of porosity and seismic structure of upper oceanic crust: importance of aspect ratios. $J$. Geophys. Res., 96:17891-17995.

Date of initial receipt: 7 February 1994

Date of acceptance: 14 October 1994

Ms 144SR-027 